\title{
PRIMEIRO A DEVOÇÃO, DEPOIS A OBRIGAÇÃO: ESTRATÉGIAS ESPACIAIS DA IGREJA CATÓLICA NO BRASIL DE 1500 A 2005. ROSENDAHL, Zeny. Rio de Janeiro: EdUERJ, 2012. 196 p.
}

"Este livro contém a dinâmica do sagrado em diferentes especialidades"

(Rosendahl, 2012:182)

Fruto de uma pesquisa realizada ao longo de três anos, Primeiro a Devoção, Depois a Obrigação constitui mais um exemplo da produção circunscrita à temática da geografia da religião que o Núcleo de Estudos e Pesquisas sobre Espaço e Cultura, o NEPEC, coordenado há vinte anos pela autora do livro, a geógrafa Zeny Rosendahl, vem divulgando junto à comunidade científica. E, muito embora ainda seja cedo para afirmar a existência na geografia brasileira de uma extensa tradição em estudos dessa natureza, não se pode negar o pioneirismo e protagonismo do NEPEC no desenvolvimento e consolidação de linhas de pesquisa da geografia da religião no Brasil.

O interesse pelo tema da religião no espaço não se configura uma novidade no extenso currículo da autora que publicou, entre outras obras alinhadas à geografia cultural, os livros Espaço e Religião: uma abordagem geográfica, em 1996, pela EdUERJ, e Hierópolis: o sagrado e o urbano, em 1999, também pela EdUERJ. Em ambos os trabalhos, a religião, mais precisamente as estratégias espaciais da Igreja Católica, ocupam posição privilegiada em suas análises sobre a "geografia da fé católica".

Agora parte dessa longa trajetória da autora encontra-se mais uma vez disponível ao leitor nesse novo livro. Dividido em quatro partes, Primeiro a Obrigação, Depois a Devoção contempla na primeira e última 
parte, estudos já publicados anteriormente nos quais a autora desenvolveu pesquisas sobre o processo de difusão da religião no espaço.

Em uma análise geral, Primeiro a Obrigação, Depois a Devoção se revela um exercício completo da abordagem geográfica sobre o fenômeno da religião. Isso porque em sua primeira parte apresenta uma série de temas que pode ser desenvolvida no âmbito dos estudos geográficos e que envolve a religião em sua especialidade latente. Os capítulos subseqüentes, por sua vez, mostram alguns desses temas desenvolvidos em investigações empíricas realizadas pela autora.

Como mencionado, o primeiro capítulo do livro, intitulado Religião e Espaço, contempla algumas das possibilidades analíticas do fenômeno religioso em sua articulação com o espaço. Trata-se de uma parte da tese de doutoramento da autora defendida em 1994 pela USP, na qual é apresentado um conjunto de cinco temas passíveis de estudo pelo geógrafo interessado em religião. Vê-se, claramente já nessa seção, que em sua abordagem, a autora dá ênfase exclusiva à dimensão geográfica do fenômeno, uma vez que todos os caminhos e temas apresentados contemplam a seara científica do geógrafo. Exemplo dessa ênfase é a perceptível preponderância das abordagens da geografia urbana no tratamento do fenômeno religioso. Temas como difusão, área de abrangência, centros de convergência, irradiação, função e forma urbana, território e territorialidade, são sugeridos para a compreensão da espacialidade da religião. Alguma pincelada de geografia histórica também se faz presente no desenvolvimento do tema da gênese dos centros religiosos no Brasil.

A segunda e terceira parte do livro intituladas, respectivamente, $A$ Territorialidade da Igreja Católica no Brasil: 1551 a 1930 e Os Territórios Regionais de 1930 a 2005, condensam em suas mais de 100 páginas, quase quatro séculos de estratégias espaciais de conquista e manutenção dos territórios religiosos ocupados pelos edifícios eclesiásticos no país. Tarefa de fôlego realizada na intenção de dar visibilidade à lógica espacial que orientou as ações executadas pela Igreja Católica.

Avançando em alguns trechos em um conteúdo histórico, esses capítulos contribuem para um entendimento da ação religiosa sobre o espaço em diferentes momentos políticos do país, demonstrando a 
articulação, nem sempre convergente, diga-se, entre o poder eclesiástico e o desenvolvimento da malha urbana brasileira.

Essa articulação constitui-se, de fato, na maior riqueza do livro. A partir da pesquisa a respeito do processo de criação, desmembramento e fragmentação das dioceses e paróquias, a partir das principais capitais regionais, é possível perceber que, nos primeiros séculos de ocupação, a estratégia espacial empreendida pela Igreja Católica, por meio de seus agentes, esteve, em diversos momentos, sintonizada à lógica oficial da metrópole portuguesa na determinação dos centros políticos e administrativos da colônia, evidenciando a clara relação entre a ação territorial da Igreja Católica e a divisão territorial do espaço brasileiro. A natureza dessa sintonia, entretanto, como demonstra a autora, sofreu alterações, especialmente durante o período compreendido pela Era Vargas e a ascensão do regime militar autoritário no Brasil.

A última parte do livro, o capítulo Hierópolis: forma, função e interação, como seu título sugere, propõe uma análise do fenômeno religioso da peregrinação e da conformação das chamadas Hierópolis, os centros de convergência de peregrinos nos quais as noções de espaço sagrado e espaço profano, segundo a autora, ganham seus mais expressivos contornos. Três hierópolis previamente investigadas, o Santuário de Jesus Crucificado, no Rio de Janeiro; a Nossa Senhora das Abadias, em Goiás; e a Santa Cruz dos Milagres, no Piauí, auxiliam na construção de um quadro de análise que revela a complexidade atual do fenômeno da peregrinação e sua articulação com as funções e formas das cidades santuário.

Em suas palavras, ao final do livro, Zeny Rosendahl ressalta a dimensão cultural do fenômeno religioso, mote fundamental de sua investigação na geografia. Em tempos nos quais os debates sobre a fé e a intolerância religiosa voltam a jogar um importante papel político e imprimem sua marca na sociedade e no espaço do país, Primeiro a Obrigação, Depois a Devoção ao lançar luz sobre as atuações da Igreja Católica na disseminação de sua fé, é um convite à reflexão. 